\title{
Cries from the Cross: Jesus and the Wrongfully Convicted
}

\section{Luke Trinka \\ Boston College School of Theology and Ministry (Brigton, MA)}

Anthony Ray Hinton, 29 years old, 30 years. Darryl Burton, 22 years old, 23 years. Jesus, around 33 years old, executed. Read these names, their ages when they were detained and incarcerated, and the years of life, or life itself, they lost. Each has a family, a story, and has suffered the cross of wrongful conviction. Speak their names. Hear their cries from the cross. "When we remember, we give voice to the victims."1

This litany represents a sliver of the thousands of women and men who have been wrongfully convicted. It is the tip of an iceberg that "lurks ominously out of view." 2 We are haunted by unknowing. We "do not know or cannot know how many other innocent people languish in our prisons." ${ }^{\prime 3}$ These individuals not only lose years but lives. Anthony lost his mother; Darryl lost precious time with his infant daughter; Jesus lost, once more, his life. And yet, their terrible condemnation to the cross was accompanied by the belief that "God's loving solidarity can transform ugliness...into beauty, into God's liberating presence."4 Within these pages, I endeavor to affirm the humanity, make known the pain, and lift up the prophetic witness of wrongfully convicted individuals. I bring forward their spiritual journeys and place them in dialectical relationship with Jesus Christ. When we see Jesus's death as a miscarriage of justice and position him in radical solidarity with the condemned, we see that when the State wrongfully incarcerates,

\footnotetext{
${ }^{1}$ James Cone, The Cross and the Lynching Tree, (Maryknoll: Orbis Books, 2011), 165.

2 Brandon Garrett, Convicting the Innocent: Where Criminal Prosecutions Go Wrong, (Cambridge: Harvard University Press, 2011), 11.

${ }^{3}$ Garrett, Convicting the Innocent, 11-12.

${ }^{4}$ Cone, Cross and Lynching Tree, 150.
} 


\section{TRINKA: CRIES FROM THE CROSS}

cages, and executes, Jesus too is crucified. We see that "they are crucifying again the Son of God" (Heb 6:6).

During his trial, Anthony Ray Hinton testified: “Jesus was prosecuted, accused falsely for things he didn't do, and all he did was try to love and save this world, and he died and suffered."5 By walking with Jesus during his marginalization, criminalization, and execution, we see an individual uniquely positioned to speak to those who experience the incalculable pain of unjust accusation and conviction. Given Jesus's growing up in a hill town on the peripheries of the Roman Empire, his family's modest means, his membership to a minority group, and his own joblessness throughout much of his adult life, Jesus was a marginalized member of society. ${ }^{6}$ The climax, though, of his marginalization is found in his criminalization and crucifixion. Rather than committing any crime, Jesus was the victim of a powerful imperial state that presumed his guilt and dangerousness. Under the cover of darkness, he was arrested. At trial, officials construed Jesus's testimony (John 18:37, Matt. 26:64) as self-incriminating. Finally, on baseless counts of "misleading the people, opposing Roman tribute, and calling himself a king," Jesus was wrongly convicted and ordered for execution. ${ }^{7}$

The pathway of persecution Jesus descended is the path that far too many have traveled. It is the road that far too many Black, Brown, and poor people have traveled, as seen in the horrifyingly disproportionate rates at which they are wrongfully convicted. Black people are only $13 \%$ of the American population, yet they constitute $47 \%$ of known exonerations. ${ }^{8}$ Innocent Black

\footnotetext{
5 Anthony Ray Hinton, The Sun Does Shine: How I Found Life and Freedom on Death Row, (New York: St. Martin's Press, 2018), 9.

6 John Meier, A Marginal Jew: Rethinking the Historical Jesus, (New York: Doubleday, 1991), 8.

7 Philip Cunningham. "The Arrest and Sentencing of Jesus: A Historical Reconstruction.” Journal of Religion \& Society. Supplement Series 1 (2004): 12.

8 Samuel Gross, Maurice Possley, and Klara Stephens. "Race and Wrongful Convictions in the United States," University of Michigan Law School Scholarship Repository, (March 7, 2017): ii.
} 


\section{TRINKA: CRIES FROM THE CROSS}

people are about seven times more likely to be convicted of murder than innocent white people. ${ }^{9}$ Innocent Black people are about twelve times more likely to be convicted of drug crimes than innocent white people. ${ }^{10}$ Low-income people are disproportionately present in both the criminal legal system and wrongful convictions. ${ }^{11}$ The unspeakable suffering of the condemned is reflected in Jesus's agonizing final hours. Before his arrest, Jesus was "in such agony and he prayed so fervently that his sweat became like drops of blood falling on the ground" (Luke 22:44). While nailed to the cross, Jesus was stripped, pierced, and cried out. And yet, Jesus's ultimate humiliation represents his ultimate identification with the poor, voiceless, lynched, and innocently convicted. ${ }^{12}$ As powerfully advanced by theologian James Cone, the cross points beyond abomination and toward "the direction of hope, the confidence that there is a dimension beyond the reach of the oppressor."13 In Jesus's resurrection is redemption and the faith that "God snatches victory out of defeat, life out of death, and hope out of despair..." 14 It is not only Jesus's pain that speaks to the innocently victimized, but also his redemption.

Jesus's story, then, is one that, as Howard Thurman notes has something to "say to those who stand with their backs against the wall."15 Jesus's witness is the witness of wrongfully convicted individuals who "are bravely taking up their parts in the drama of salvation unfolding in front of us."16 Anthony Ray Hinton - who spent 30 years on death row for two capital murders he did not commit - describes his own criminalization and crucifixion with force. "It was nothing less

\footnotetext{
${ }^{9}$ Gross, Possley, Stephens, "Race and Wrongful Convictions," ii.

10 Ibid., iii.

11 “Race, Poverty, and Mass Incarceration," Montana Innocence Project, accessed November 16, 2020.

12 Meier, Marginal Jew, 8.

13 Cone, Cross and Lynching Tree, 161-162.

14 Ibid.

15 Howard Thurman, Jesus and the Disinherited, (Boston: Beacon Press, 1976), 1.

${ }^{16}$ Bishop Mark J. Seitz, El Paso's Bishop Mark Seitz: Black lives matter, National Catholic Reporter, June 4, 2020.
} 


\section{TRINKA: CRIES FROM THE CROSS}

than a lynching - a legal lynching - but a lynching all the same."17 "My only crime was being born black, or being born black in Alabama." 18 "Two white men came and got me, falsely accused me, it was a white mob that prosecuted me, a white judge that sentenced me, a white jury that convicted me." ${ }^{19}$ Similar to Jesus's own victimization amidst a kind of lynch mob-hysteria and imperial violence, Hinton was maliciously criminalized. After he was caged, Hinton felt utter abandonment: "My God had failed and left me to die." ${ }^{20}$ For the next three years, he remained silent on death row. It was not until the sorrowful wailing of another man on death row - a voice in the night, "Oh God. Help me God..." - that stirred his soul and broke his years of silence. ${ }^{21}$

I wasn't expecting to have my heart break that night...It was a revelation to realize that I wasn't the only man on death row. I was born with the same gift from God we are all born with - the impulse to reach out and lessen the suffering of another human being. It was a gift, and we each had a choice whether to use this gift or not. ${ }^{22}$

On this dark night, in what Hinton describes as "the most desolate and dehumanizing place on earth," he chose faith. ${ }^{23} \mathrm{He}$ chose to minister to another man on death row. In these liminal moments, Hinton embraced a God that "may sit high, but he looks low. He's looking down here in the pit." ${ }^{24}$ In his act of self-giving, of reaching out beyond himself to counsel and abide with another human being, he found his faith. Here, we might pause and rest in the biblical imagery of Luke's gospel. Amidst a duress that surely challenged every ounce of his humanity, an angel visited Jesus as he too wailed for relief during his last surviving hours (Luke 22:43). Luke tells us that the angel consoled and strengthened Jesus. In these lowliest of places - from the death row on

\footnotetext{
${ }^{17}$ Hinton, Sun Does Shine, 5.

${ }^{18}$ Hinton, Sun Does Shine, 5.

19 Anthony Ray Hinton, “Lynching in America: Confronting the Legacy of Racial Terror,” Equal Justice Initiative.

${ }^{20}$ Hinton, Sun Does Shine, 84.

21 Ibid., 117.

22 Ibid.

23 Ibid., 117-18.

24 Ibid., 116-17.
} 


\section{TRINKA: CRIES FROM THE CROSS}

the Mount of Olives to that of Alabama's Holman State Prison - God was present. That night, Hinton heard his prophetic call from a God that is present precisely within struggle, injustice, and inhumanity. God is made possible when humans strive to see the light beyond darkness, when they open themselves to the possibility of being held by even a ray of goodness. God is made real when we see, hear, and reach out to one another.

In confronting his own rugged road to the cross, Darryl Burton battled an internal rage that initially made God untenable. Despite a strong alibi, no physical evidence or suggested motive, and an eyewitness identification that did not match Burton's appearance, he was wrongly convicted of capital murder. Burton experienced his own Golgotha when he arrived at the Missouri State Penitentiary and saw a sign that read: "Welcome to Missouri State Pen. Leave all your hopes, family, and dreams behind." 25 For the next fifteen years, Burton endured "hell on earth - filled with violence, evil, and hate." 26 And yet, even as he descended into the "valley of the shadow of death" (Psalm 23:4), Burton discovered an opening, a horizon beckoning him forward. His ultimate marginalization was his ultimate empowerment. Nearly twenty years into his incarceration and without anywhere left to turn, he wrote his most important letter: to Jesus. ${ }^{27}$ “Dear Jesus Christ - If you're real and you know all things, you and I know I'm innocent. If you help me get out of this place, not only will I serve you, but I will tell the world about you. Sincerely yours, Darryl Burton."28 Just as Jesus reached out to his Father as he endured crucifixion, Burton reached out to the wrongly convicted Jesus. In doing so, he found a profound succor and strength

\footnotetext{
${ }^{25}$ Darryl Burton, "Sermon on Hope and Forgiveness at Church of the Resurrection," United Method Church of the Resurrection Leawood, October 30, 2016.

${ }^{26}$ Burton, "Sermon on Hope."

${ }^{27}$ Nadia Pflaum, “Miracle Man: Darryl Burton forgives St. Louis. He just doesn't trust it," Riverfront Times, September 23, 2009.

${ }^{28}$ Laura Bauer, "From the pit to the pulpit: Inmate 153063 will become a megachurch pastor in Leawood," Kansas City Star, December 24, 2015.
} 


\section{TRINKA: CRIES FROM THE CROSS}

that enabled him to live. ${ }^{29} \mathrm{He}$ "read what Jesus said on the cross: 'Forgive them, Father, for they know not what they do.' I thought, 'If he could do that on the cross, I'll try to do it while I'm still alive, here on Earth." ${ }^{30}$ In his surrender, Burton made a way out of no way, and found his prophetic voice. He journeyed from "the pit to the pulpit," from Inmate 153063 to his current role as a congregational care pastor. ${ }^{31}$ Ultimately, Burton now sees his vocation as fundamentally grounded in God: "I'm doing things today that can only be because of the grace and mercy of God. I have come to embrace my walk of faith. I pray to be a humble servant in my ministry." 32

As seen from these $1^{\text {st }}$ and $21^{\text {st }}$ century narratives, the shadow of injustice is long, dark, and deep. It is a shadow that stretches from Jesus's wrongful execution through the cross that too many innocent men and women wrongfully bear today. We continue to crucify the sons and daughters of God. Amending the famous lines from To Kill a Mockingbird, we've done it before and we'll do it tonight and we'll do it again and when we do it - seems only children weep. ${ }^{33}$ What is the call, then, for people of faith and conscience? I believe it is to follow the timeless instruction of Rev. Dr. Martin Luther King, Jr., and his challenge to us to be creatively maladjusted. ${ }^{34}$ This is a maladjustment that refuses to be neatly accommodated to the injustices of convicting the innocent and our age of the New Jim Crow. It is a maladjustment that as St. Bonaventure implores, asks not just for understanding but asks for the fire. It is a maladjusted modus operandi that hears the prophetic call announced by Anthony and Darryl, and with them cries out from the cross. It is a maladjusted attitude that denounces Jesus's death as utterly unjust. Indeed, King was correct when

\footnotetext{
${ }^{29}$ Thurman, Jesus and the Disinherited, 1.

${ }^{30}$ Pflaum, "Miracle Man."

${ }^{31}$ Ibid.

32 Burton, "Sermon on Hope."

${ }^{33}$ Harper Lee, To Kill a Mockingbird, (Philadelphia: Lippincott, 1960), 243.

${ }^{34}$ Martin Luther King, Jr., "The Christian Way of Life in Human Relations," in The Papers of Martin Luther King, Jr. Vol. VI: Advocate of the Social Gospel, ed. Clayborne Carson (Berkeley: University of California Press, 2007), 327.
} 


\section{TRINKA: CRIES FROM THE CROSS}

he said, "The world is in desperate need of such maladjustment." 35 Only through a radical retraining of our sight may we see that what we do unto the prisoner and condemned, we do unto Jesus (Matthew 26:40). Only through a radical reorientation may we courageously practice what Hebrews 13:3 instructs: Remember those who are in prison, as though you were there in prison with them, those who are being tortured as though you yourselves were being tortured. In remembering, walking with, and getting proximate to the wrongfully convicted, we see that with their backs against the wall they found a way forward, a way forward that we are called to follow. For when we follow the way of Jesus and the wrongly condemned, we might bring Isaiah's prophetic vision of God's feast of joy, peace, and reconciliation, for all peoples into being (Isaiah 25:6).

\section{Bibliography}

Burton, Darryl. "Sermon on Hope and Forgiveness at Church of the Resurrection." United Method Church of the Resurrection Leawood (October 30, 2016).

Bauer, Laura. "From the pit to the pulpit: Inmate 153063 will become a megachurch pastor in Leawood.” Kansas City Star (December 24, 2015).

Cone, James. The Cross and the Lynching Tree. Maryknoll: Orbis Books, 2011.

Cunningham, Philip. "The Arrest and Sentencing of Jesus: A Historical Reconstruction.” Journal of Religion \& Society. Supplement Series 1 (2004).

Garrett, Brandon. Convicting the Innocent: Where Criminal Prosecutions Go Wrong. Cambridge: Harvard University Press, 2011.

Gross, Samuel. Possley, Maurice. Stephens, Klara. "Race and Wrongful Convictions in the United States." University of Michigan Law School Scholarship Repository (March 7, 2017).

Hinton, Anthony Ray. The Sun Does Shine: How I Found Life and Freedom on Death Row. New

\footnotetext{
${ }^{35}$ King, Papers, 327.
} 


\section{TRINKA: CRIES FROM THE CROSS}

York: St. Martin's Press, 2018.

Hinton, Anthony Ray. "Lynching in America: Confronting the Legacy of Racial Terror." Equal Justice Initiative.

King Jr., Martin Luther. "The Christian Way of Life in Human Relations." The Papers of Martin Luther King, Jr. Vol. VI: Advocate of the Social Gospel. Edited by Clayborne Carson. Berkeley: University of California Press, 2007.

Lee, Harper. To Kill a Mockingbird. Philadelphia: Lippincott, 1960.

Meier, John. A Marginal Jew: Rethinking the Historical Jesus. New York: Doubleday, 1991.

Montana Innocence Project. "Race, Poverty, and Mass Incarceration." https://mtinnocenceproject.org/race-and-poverty/

Pflaum, Nadia. "Miracle Man: Darryl Burton forgives St. Louis. He just doesn't trust it." Riverfront Times (September 23, 2009).

Seitz, Bishop Mark J. “El Paso's Bishop Mark Seitz: Black lives matter.” National Catholic Reporter (June 4, 2020).

Thurman, Howard. Jesus and the Disinherited. Boston: Beacon Press, 1976. 